\title{
Peat swamp forest and the false gharial Tomistoma schlegelif (Crocodilia, Reptilia) in the Merang River, eastern Sumatra, Indonesia
}

\author{
Mark R. Bezuijen, Grahame J. W. Webb, Pandu Hartoyo and Samedi
}

\begin{abstract}
Tomistoma schlegelii is a threatened crocodilian whose current range is restricted to Sumatra, Borneo (Kalimantan and Sarawak) and Peninsular Malaysia. During surveys undertaken in eastern Sumatra in 19951996, 15 T. schlegelii nests were located in peat swamp forest along a single tributary, the Merang River. No other areas with equivalent nest densities have yet been described. Although much peat swamp forest has been lost to logging and fire, it remains the dominant habitat in most of the current range of $T$. schlegelii. In the Merang River the peat swamp and $T$. schlegelii are
\end{abstract}

\section{Introduction}

The false gharial Tomistoma schlegelii Müller 1838 is a large, freshwater crocodilian restricted to eastern Sumatra, Borneo (Kalimantan and Sarawak) and Peninsular Malaysia. Despite being the largest predator (4-5 m total length) throughout much of its range, its global Red List status was until recently classified as Data Deficient by the International Union for Conservation of Nature (IUCN) (IUCN, 1996; Ross, 1998a) and it was considered one of the world's least known crocodilians. Concern about its status and the ongoing loss of swamp habitats it was known to occupy (Thorbjarnarson, 1992; Sebastian, 1993a, b) prompted regional surveys and new research on its status, distribution, biology and ecology (Muin \& Ramono, 1994; Ramono, 1994; Bezuijen et al., 1995a, b, 1997; Ross et al., 1998; Simpson et al., 1998). IUCN subsequently revised the global status of $T$. schlegelii to Endangered (using criterion C1: estimated $<2500$ mature individuals and continuing decline of at least 20 per cent within 5 years or two generations) (Ross, 1998b; Hilton-Taylor, 2000), although no proper estimate of global population size is available.

This paper is based on surveys undertaken in eastern Sumatra during July-October (the dry season) in 1995

*Mark R. Bezuijen (Corresponding author) and Grahame J. W. Webb Wild life Management International Pty Limited, PO Box 530, Karama, NT Australia 0812; "Present address: PO Box 183, Ferny Creek, Victoria, Australia 3786. E-mail: mbezuijen@hotmail.com

Pandu Hartoyo and Samedi Directorate-General of Forest Protection and Nature Conservation, Manggala Wanabakti Blok VII Lt. 7. Jakarta Pusat, Java, Indonesia

Revised manuscript accepted for publication 4 June 2001 threatened by a series of ongoing activities and both may be lost unless some form of innovative management programme is introduced. Peat swamp forest supports a range of other rare and threatened species, and would appear to have high conservation value. This paper reviews current information on the role of peat swamp forest in the ecology of $T$. schlegelii and describes the conservation threats to $T$. schlegelii in the Merang River.

Keywords Crocodilian, false gharial, Indonesia, peat swamp forest. and 1996; a total of 90 days of fieldwork, including 50 nights of spotlighting, were conducted on 10 rivers in the provinces of South Sumatra (Sumatera Selatan), Jambi and Riau (Bezuijen et al., 1995a, b, 1997, 1998). We describe the role of peat swamp forest as nesting and foraging habitat for $T$. schlegelii, and discuss the management issues associated with the conservation of $T$. schlegelii and the habitats it occupies in the Merang River, eastern Sumatra, Indonesia.

\section{Study area}

The Merang River is a $66-\mathrm{km}$ freshwater tributary of the Lalan River, in South Sumatra Province (1 ${ }^{\circ} 59^{\prime}$ S, $104^{\circ} 00^{\prime} \mathrm{E}$; Fig. 1). It is one of few rivers in eastern Sumatra where $T$. schlegelii is known to live and nest regularly (Bezuijen et al., 1998). From the mouth to $45 \mathrm{~km}$ upstream, the river banks have been modified by logging and burning, and support secondary forest (approximately $10 \mathrm{~m}$ high), scrub (3-5 m) and grasses, with areas of cleared or burnt banks. Side creeks are few in number and are typically narrow ( $<1 \mathrm{~m}$ wide), shallow $(<0.5 \mathrm{~m}$ deep) and drain completely at low tide (there is usually one tidal cycle per day in eastern Sumatra, and tidal influence extends upstream into freshwater areas, Hadi et al., 1977). There is little swamp adjacent to the river.

The upper reaches (46-66 $\mathrm{km}$ upstream) are without tidal influence, and in 1996 had not been logged for over a decade. They showed no evidence of recent burning, and retained mature secondary and some primary peat swamp forest. The upper reaches are characterized by extensive swamp adjacent to the mainstream (extending up to several hundred metres into the forest), with 


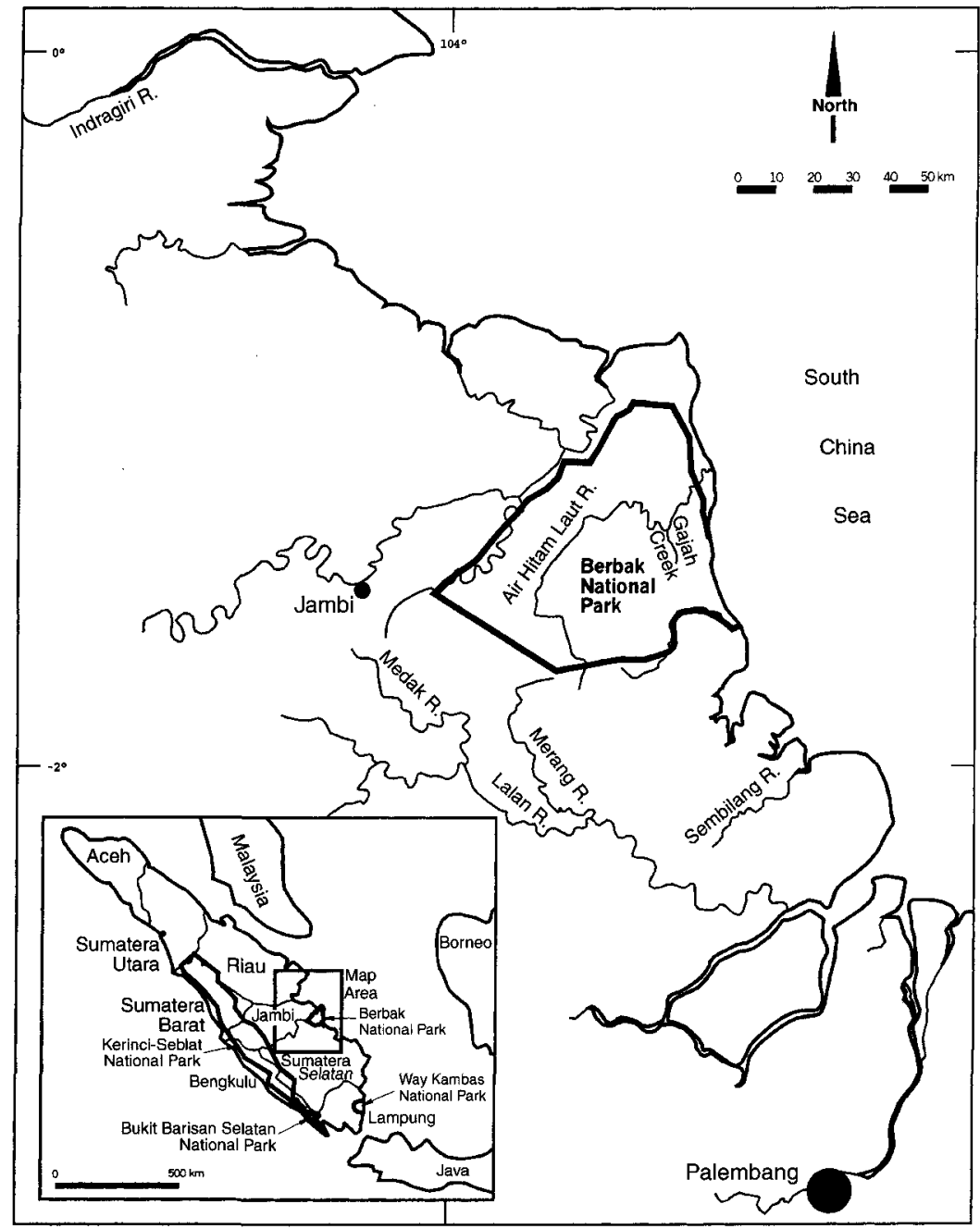

Fig. 1 Eastern Sumatra, Indonesia, illustrating river systems mentioned in the text numerous side creeks and discrete peat mounds. These mounds, up to a few metres high and $8-50 \mathrm{~m}$ in circumference (5-200 sq $\mathrm{m}$ ), usually supported one or several trees. Although not quantified, larger mounds usually supported larger trees. All $T$. schlegelii nests on the Merang River were recorded in the upper reaches, 50-60 km upstream, although individual $T$. schlegelii were observed from the mouth to $63 \mathrm{~km}$ upstream (Bezuijen et al., 1995b, 1997).

The upper reaches of the Merang River are approximately $20 \mathrm{~km}$ from the western boundary of Berbak National Park in Jambi Province (Fig. 1). The Park encompasses more than 171,000 ha of swamp forest, with possibly the most intact peat swamp forest remaining in South-east Asia (Davie \& Sumardja, 1997).

\section{Nesting}

Most T. schlegelii sightings and nest records in the literature are from ombrogenous (rain-fed) peat swamp forest, along slow-flowing freshwater tributaries. Some are under tidal influence and others not, and most adjoin swamps and lakes, often fringed with floating aquatic macrophytes (Butler, 1905; Witkamp, 1925; Frazier \& Maturbongs, 1990; Frazier, 1994; Sebastian, 1994; Bezuijen et al., 1995b, 1997; Lading \& Stuebing, 1997; Ross et al., 1998; Simpson et al., 1998). Peat swamp forest, historically one of the most extensive lowland vegetation communities in eastern Sumatra, Kalimantan, and Sarawak, has waterlogged, anaerobic soil and receives most of its nutrient and water input from rainfall and the slow decomposition of organic matter (Blasco et al., 1983; Whitten et al., 1984; MacKinnon et al., 1996). This gives rise to peat soil (a soil with 65 per cent or more organic matter content, Driessen, 1978), with low soil and water nutrient content, and acidic 'blackwater' rivers with relatively low levels of primary productivity (Whitten et al., 1984; MacKinnon et al., 1996).

Fifteen nests (new and old) in peat swamp forest on the Merang River, and one old nest on an adjacent 
tributary, the Medak River (Fig. 1), had several common characteristics (Bezuijen et al., 1998):

- nests were compact mounds, 117-144 cm basal diameter and $36-60 \mathrm{~cm}$ high. All consisted of peat soil and leaf litter raked up by the females;

- each nest was situated at the base of a large tree, themselves on discrete peat mounds typically 25-30 $\mathrm{m}$ circumference (50-72 sq $\mathrm{m}$ ), and demarcated by narrow, shallow channels of water;

- most nest sites (15 nests) were adjacent to the main stream draining a swamp; one nest was about $100 \mathrm{~m}$ away from the main stream;

- nest sites were within 2-4 m of a permanent waterway, and the nest base was $0.5-1.5 \mathrm{~m}$ (mode $1.0 \mathrm{~m}$, $n=15$ ) above water level at the time they were located; and

- nest sites were always in shaded locations, with all nests receiving at least 50 per cent shade, and 13 nests (81 per cent) receiving $80-100$ per cent shade in a day. There are no other documented $T$. schlegelii nest data from Sumatra for comparison, but local people elsewhere in Sumatra, and documented nest records from Borneo and Peninsular Malaysia (Butler, 1905; Witkamp, 1925; Cox \& Gombeck, 1985; Lading \& Stuebing, 1997; Ross et al., 1998), indicate T. schlegelii also nests in freshwater swamp forest and secondary lowland forest. Freshwater swamp forest, which is periodically inundated by mineral-rich floodwaters and which has less acidic water and soils and greater primary productivity than peat swamp forest, is much less extensive in Sumatra and Kalimantan than peat swamp forest (Whitten et al., 1984; MacKinnon et al., 1996). Two $T$. schlegelii nests were observed in Berbak National Park, eastern Sumatra, by local forestry officers in the mid-1980s; although the habitat was not recorded, the Park supports extensive peat swamp and freshwater swamp forest. T. schlegelii were observed recently during spotlight surveys in the Park (Bezuijen et al., 1997, 1998).

Logging, burning, shifting cultivation and other activities have resulted in a mosaic of derived, secondary forests in successive stages of regrowth along many of the lowland waterways of eastern Sumatra (pers. obs.). Historically these areas contained peat swamp, freshwater swamp or moist evergreen forest (Blasco et al., 1983). Local people reported T. schlegelii nesting along five rivers with secondary forest in eastern. Sumatra (Bezuijen et al., 1997). Although not quantified precisely, these rivers appeared to differ from the Merang River in a range of edaphic, hydrological and structural attributes, including: well-defined, often sloping clay/mud river banks, absence of peat mounds and swamp, muddy (not black) waters and less acidic waters ( $\mathrm{pH} 4.5-5.5$ compared to $\mathrm{pH} \mathrm{3-4} \mathrm{along} \mathrm{the} \mathrm{Merang}$ River) (Bezuijen et al., 1997). Recent logging, burning and agricultural activity were widespread in the upper and lower reaches of these rivers.

Witkamp (1925) described three T. schlegelii nests in East Kalimantan, all of which were in peat swamp forest similar to that found in the Merang River. Nests were several metres from the river's edge and positioned between trees. Three additional nests in East Kalimantan were described by Ross et al. (1998), with one in peat swamp forest, one in 'secondary forest with few streams' and the third in 'post-fire freshwater swamp regrowth'. In Sarawak, local hunters report that $T$. schlegelii nests along the banks of 'blackwater tributaries' in peat swamp forest (Cox \& Gombeck, 1985), and a T. schlegelii nest was recently found in a logged peat swamp forest, at the base of a tree, one metre from a stream (Lading \& Stuebing, 1997; Stuebing et al., 1998). A nest found on a stream bank in Selangor State (Peninsular Malaysia), was reported to be 'on a little high ground with swamps all round' (Butler, 1905), in a region of peat swamp forest.

The attributes of peat swamp forest that make it suitable for $T$. schlegelii nesting are unclear. Successful nesting along the Merang River (Bezuijen et al., 1997) indicates that internal nest temperatures do not exceed lethal limits, which could reflect both the energy content of the peat and the tendency to locate nests in the shade. In recently logged swamp forest in eastern Sumatra, peat mounds tended to be absent, or when present around the bases of trees, appeared too small to support T. schlegelii nests (Bezuijen et al., 1997); it is unclear whether these mounds were an original or derived state.

\section{Foraging and other resources}

Although limited, the available data indicate that $T$. schlegelii has a broad diet, which includes: fish, shrimp, monkeys, wild pigs, snakes, birds and other mammals and reptiles (Galdikas \& Yeager, 1984; Bezuijen $e t$ al., 1997). The diet of juvenile T. schlegelii is largely unknown, but the stomach contents of three juveniles captured on the Merang River contained shrimp (Bezuijen et al., 1997). Other juvenile T. schlegelii prey items probably include small aquatic invertebrates and fish. It seems unlikely that food availability is itself an important factor linking $T$. schlegelii to peat swamp forest. The faunal assemblages of peat swamp forest are impoverished compared to freshwater swamp forest (Whitten et al., 1984; MacKinnon et al., 1996), although some potential prey, for example long-tailed macaque Macaca fascicularis and silvered langur Presbytis cristata, occur at higher densities in peat swamp forest than in other lowland forest along rivers (MacKinnon et al., 1996). Galdikas \& Yeager (1984) observed predation of a long-tailed macaque by a $T$. schlegelii in Tanjung Puting National Park, Central Kalimantan. 
The abundance of peat, leaf litter and fallen wood debris in peat swamp forest provides ample cover for $T$. schlegelii of all sizes to hide and avoid predation. The extensive side creeks and swamp along the Merang River may provide more foraging and nesting habitat than along lowland rivers with little swampy ground adjacent to the mainstream.

\section{Conservation threats in the Merang River}

At the time these surveys were undertaken, the Merang River catchment was under a 20-year logging concession, which expired in 2000 . Until at least 1996 a logging mill, a few hundred personnel and some fishing families lived about $42 \mathrm{~km}$ upstream from the mouth. A logging railway provided access to forest beyond the terminal reaches of the river. Logs were transported by railway to the mill, then floated to a larger mill on the adjoining Lalan River. A small fishing village at $\mathrm{km} 45$ was the upstream limit of permanent settlement, and from the mouth to $\mathrm{km} 45$ the river was subject to regular human activity, including motorized and non-motorized boat traffic, vegetation clearance, firewood collection and fishing.

In South Sumatra Province a traditional system of river ownership (lebak lobang) regulates fishing activity on some rivers. Annual district auctions are held for villages to bid for exclusive, 1-year fishing rights to a river or portion of river. From 1987 to 1995 the annual fishing lease for the upper reaches was owned by several families who lived at $\mathrm{km} \mathrm{45}$. In 1995, 20-30 people were resident at this village, and only eight fishermen regularly visited the upper reaches where the peat swamp forest and nesting $T$. schlegelii are found. Due to a combination of exclusive fishing access and absence of recent logging, the upper reaches had not been subjected to high levels of disturbance for at least the last decade.

In 1996 increased logging and fishing activities were apparent in the upper reaches. The regional logging company's strategy for 1996-1998 was to target the Merang River from 50 to $60 \mathrm{~km}$ upstream. At the same time, a new fisherman won exclusive fishing rights to the upper reaches. These changes resulted in the use of two motorized boats, and construction of four permanent huts, in the upper reaches (59.5 km upstream), and doubled the number of residents at $45 \mathrm{~km}$ upstream to 50-60 people. In 1996 fishing intensity had increased substantially, and was reported as approximately twice that in 1995. Most side creeks in the upper reaches were blocked with fish traps, and three fish traps blocked the mainstream.

Conservation threats to $T$. schlegelii documented in 1996 included: habitat loss and fragmentation, increased noise and visual disturbance as a result of elevated fishing and logging activity, incidental drowning in fishnets and traps, and eigg predation by introduced pigs Sus scrofa. Small-scale, incremental removal of potential nesting habitat was observed along the mainstream during hut construction, and will probably increase as human settlement increases. Direct loss of nesting habitat as a result of legal logging appeared to be minor because Indonesian law prohibits logging closer than $250 \mathrm{~m}$ to waterways (although T. schlegelii were recorded on some side creeks extending more than $200 \mathrm{~m}$ into the forest, Bezuijen et al., 1997).

Although the relative importance of these threats is unclear, we note the following. Between 1995 and 1996 local people reported that at least six $T$. schlegelii were caught during fishing activities; three were found drowned and three, still alive, were released. These included two individuals observed during our visits: one had been snagged on a fish hook and line set in the midstream, and one was caught in a fish trap. These individuals were 0.6 and $1.9 \mathrm{~m}$, respectively (Bezuijen et al., 1997), indicating that a range of different sized $T$. schlegelii are susceptible to incidental capture. Mortality of $T$. schlegelii during fishing activities will probably increase as human settlement increases.

Of seven documented $T$. schlegelii nests on the Merang River in 1995, four (57 per cent) appeared to have been predated by wild pigs (Bezuijen et al., 1997). At least some female $T$. schlegelii remain beside their nests when visited by humans (M. Bezuijen, pers. obs.), and may defend their nests against predators. Dead or rotten eggs in a clutch, in the absence of females, provide olfactory cues that may attract predators, but does not necessarily contribute to increased predation rates of live embryos (Webb et al., 1983). According to local fishermen, who apparently leave nests alone if discovered, humans do not consume $T$. schlegelii eggs and do not deliberately kill $T$. schlegelii (pers. comm.). However, occasional human consumption of $T$. schlegelii eggs was reported on other rivers in eastern Sumatra (Bezuijen et al., 1997) and could occur on the Merang River.

In captivity $T$. schlegelii is considered to be a relatively shy crocodilian, that is easily stressed (M. Bezuijen, pers. obs.; J. Jong Soon, pers. comm.). If so, nesting female $T$. schlegelii may have low tolerance to elevated human activity, which may lead to nest abandonment.

\section{Discussion}

In South-east Asia the highest densities of $T$. schlegelii and the majority of $T$. schlegelii nests so far documented are in locations with relatively intact and extensive ombrogenous peat swamp forest. These records, although scattered and incomplete, suggest peat swamp 
forest was and remains an important habitat for this species. Unburnt forest that has not been logged appears to provide suitable platforms for nesting that are elevated above water level, and suitable conditions (food, temperature and water) to sustain adults and newly hatched young. It also appears to provide suitable materials for nest construction, which meet the needs of gas and water exchange, and acceptable incubation temperatures, within the final nest mound. Records in the literature from freshwater swamp forest and modified, secondary forest confirm that $T$. schlegelii is not restricted to peat swamp forest, although it may be a favoured habitat; it is not unusual for crocodilian adults to live and nest in relatively small subsets of the total habitats that they occupy through different life stages (Webb et al., 1983).

Records from modified, secondary forest suggest that it supports fewer $T$. schlegelii than undisturbed habitats. For example, local people in eastern Sumatra commonly stated that numbers of $T$. schlegelii had declined in the last few decades as human activity had increased. Nesting reports from previously logged or burnt areas were typically of single nests that were often several years old (Bezuijen et al., 1997).

The 1997/1998 fires in Sumatra and Kalimantan (Kinnaird \& O'Brien, 1998; Barber \& Schweithelm, 2000) may have destroyed large areas of $T$. schlegelii nesting habitat. Peat swamp forest is vulnerable to burning, which removes peat layers and subsurface root formations, and exposes the soil to erosion, slumping, hydrological changes and weed invasion (GOI-World Bank, 1995). In eastern Sumatra the banks of a tributary surveyed in 1995 (Bezuijen et al., 1995b) had been burnt in 1994, and the post-fire vegetation was grassland with low tree regrowth. No T. schlegelii were recorded, and local people reported that none had been seen since the fire. In contrast, $T$. schlegelii was recorded in adjacent tributaries that had not been burnt (Bezuijen et al., 1995b). That fire can lead to crocodilians abandoning areas of traditional nesting habitat has been demonstrated in northern Australia. In one case, all nesting by Crocodylus porosus in a freshwater swamp ceased after a fire and, despite the recovery of the vegetation after 2 years, nesting is virtually non-existent 14 years later (G. Webb, pers. obs.). The ongoing, incremental loss or modification of swamp forest habitat in eastern Sumatra and elsewhere in South-east Asia (Khan, 1995; Bezuijen et al., 1998; Ross, 1998a) is probably the greatest threat to the long-term global status of $T$. schlegelii.

Other human-related threats to $T$. schlegelii in eastern Sumatra include incidental drowning in fish nets and traps, and occasional egg consumption. Fishing-related mortality of $T$. schlegelii is widespread; for example, 21 of 23 fishermen interviewed in three provinces of eastern
Sumatra had witnessed T. schlegelii caught in fishnets or traps (Bezuijen et al., 1997). Although subject to trade between the 1950s and 1970s, T. schlegelii skin and flesh are widely recognized among local people as having no commercial value. No evidence of commercial trade was observed in eastern Sumatra in 1995-1996 (Bezuijen et al., 1997). Only one report of flesh consumption was recorded, from a fisherman in Jambi Province, who claimed he had observed a member of the Kubu tribe consume T. schlegelii flesh (Bezuijen et al., 1997).

On the Merang River, the most significant human threats to T. schlegelii in 1996 resulted from increasing human activity associated with the steady upstream movement of permanent and semi-permanent settlements. Unsurveyed since 1996, it seems likely that the status of the peat swamp forest and nesting aggregation of wild T. schlegelii has declined. Bezuijen et al. (1998) recommended that a management plan be developed for the Merang River, and that the upper reaches be included within a regional conservation strategy for forested coastal wetlands (GOI-World Bank, 1995; Davie \& Sumardja, 1997). This regional strategy, which proposed that the southern boundary of Berbak National Park be extended to encompass the Sembilang River system (Fig. 1), was supported by the provincial and local government in South Sumatra Province in 1996, and was in the process of being gazetted prior to the onset of the economic crisis and changes in national government in 1998 (J. Davie, pers. comm.).

The inclusion of the Merang River into this regional strategy would have numerous advantages. No other rivers are currently known that support comparable $T$. schlegelii nest densities, many rivers in eastern Sumatra no longer retain intact and extensive peat swamp forest, and a range of other rare and threatened fauna have been documented along the Merang River, including tigers Panthera tigris, asiatic elephants Elephas maximus, flat-headed cats Priornailurus planiceps, whitewinged wood ducks Cairina scutulata and Storm's storks Ciconia stormi (Lambert, 1988; Danielsen \& Verheugt, 1990; Bezuijen, 2000; M. Bezuijen, unpubl. data; local people, pers. comm.).

With the expiry of the Merang River logging concession in 2000, now may be an opportune time for Indonesia to reconsider proposals for protecting the peat swamp forest and its T. schlegelii population. Any such proposal would need to provide a sustainable future for the local people who depend on the waters for fishing and other resources. The traditional system of exclusive annual fishing rights and history of low intensity fishing in the upper reaches are conducive to the development of an innovative management strategy for the river. Some level of external financing and assistance may be needed. A more detailed survey to 
assess the current status of the peat swamp forest and T. schlegelii population is also warranted.

\section{Acknowledgements}

Research in eastern Sumatra was conducted under a 3-year co-operative project between the DirectorateGeneral of Forest Protection and Nature Conservation (PHPA) Indonesia, Wildlife Management International Pty Limited (WMI) and the Crocodile Specialist Group (CSG) of the IUCN-SSC World Conservation Union, and sponsored by the Global Guardian Trust, WMI, the German Leather Industry Association (Internationaler Reptillederverband-IRV), CSG and the Asian Conservation and Sustainable Use Group. Ecology Australia Pty Ltd (EA) and F. Hape provided technical resources for writing this paper. Dr J. Davie (University of Queensland) provided information on the coastal conservation strategy for eastern Sumatra. We thank G. Carr (EA), J. Davie, C. Manolis (WMI) and three anonymous reviewers for critical comments on a draft manuscript.

\section{References}

Barber, C.V. \& Schweithelm, J. (2000) Trial by Fire. Forest Fires and Forestry Policy in Indonesia's Era of Crisis and Reform. World Resources Institute (Forest Frontiers Initiative), Washington, DC.

Bezuijen, M.R. (2000) The occurrence of the flat-headed cat Prionailurus planiceps in south-east Sumatra. Oryx, 34, 222-226.

Bezuijen, M.R., Cannucciari, P., Ramono, W.S. \& Webb, G.J.W. (1995a) Project Tomistoma. Field trip to Palembang, Sumatera Selatan, Indonesia. 14 March-3 April 1995. Unpublished Report. Wildlife Management International Pty Limited, Darwin, Australia.

Bezuijen, M.R., Cannucciari, P., Manolis, S.C., Samedi, Kadarisman, R. \& Simpson, B.K. (1995b) Project Tomistoma. Field Expedition to the Lalan River and its Tributaries, South Sumatra, Indonesia, August-October 1995: Assessment of the Distribution, Abundance, Status and Nesting Biology of the False Gharial (Tomistoma schlegelii). Unpublished Report. Wildlife Management International Pty Limited, Darwin, Australia.

Bezuijen, M.R., Hartoyo, P., Elliott, M. \& Baker, B.A. (1997) Project Tomistoma. Second Report on the Ecology of the False Gharial (Tomistoma schlegelii) in Sumatera. Unpublished Report. Wildlife Management International Pty Limited, Darwin, Australia.

Bezuijen, M.R., Webb, G.J.W., Hartoyo, P., Samedi, Ramono, W.S. \& Manolis, S.C. (1998) The false gharial (Tomistoma schlegelii) in Sumatra. In Crocodiles. Proceedings of the 14th Working Meeting of the Crocodile Specialist Group, IUCN - The World Conservation Union, pp. 10-31. IUCN/SSC Crocodile Specialist Group, Gland, Switzerland.

Blasco, F., Laumonier, Y. \& Purnajaya (1983) Tropical vegetation mapping: Sumatera. Biotrop Bulletin in Tropical Biology, 22, 1-61.
Butler, A.L. (1905) The eggs and embryos of Schlegel's Gavial (Tomistoma schlegelii, S. Muller). Journal of Federal Malay States Museums, 1, 1-2.

Cox, J.H. \& Gombeck, F. (1985) A Preliminary Survey of the Crocodile Resource in Sarawak, East Malaysia. IUCN/WWF Project no. MAL 74/85. Unpublished Report. World Wildlife Fund Malaysia and the National Parks and Wildlife Office, Forest Department, Sarawak, Malaysia.

Danielsen, F. \& Verheugt, W.J.M. (1990) Integrating Conservation with Land-use Planning in the Coastal Region of South Sumatra. With Contributions from H. Skov, R. Kadarisman, U. Suzwarman and A. Purwoko. PHPA/AWB-Indonesia, Bogor.

Davie, J. \& Sumardja, E. (1997) The protection of forested coastal wetlands in Southern Sumatra: a regional strategy for integrating conservation and development. Pacific Conservation Biology, 3, 366-378.

Driessen, P.M. (1978) Peat soils. In Soils and Rice, pp. 763-779. IRRI, Los Banos.

Frazier, S. (1994) A Preliminary Dry Season Crocodile Survey of Suaka Margasatwa Danau Sentarum (Lake Sentarum Wildlife Reserve) in Kalimantan Barat, Indonesia. Unpublished Report for the Directorate-General of Forest Protection and Nature Conservation and the Asian Wetland Bureau. UK-Indonesia Tropical Forest Management Project, Bogor.

Frazier, S. \& Maturbongs, R.A. (1990) Report on an Initial Series of Crocodile Surveys in East and Central Kalimantan, Indonesia (1 August-22 October 1990). Unpublished Report. FAO/PHPA Project no. GCP/INS/060/JPN, Jayapura.

Galdikas, B.M.F. \& Yeager, C.P. (1984) Crocodile predation on a crab-eating macaque in Borneo. American Journal of Primatology, 6, 49-51.

GOI-World Bank (1995) The Sembilang Region, South Sumatra: Integrated Mangrove Conservation and Land Use Management Plan. Unpublished Report for the Directorate-General of Forest Protection and Nature Conservation, Ministry of Forestry. ENEX, New Zealand, in conjunction with P.T. Manggala Epsilon Sigma, Jakarta.

Hadi, S., Hanson, A.J., Koesoebiono, Mahlan, M., Purba, M. \& Rahardjo, S. (1977) Tidal patterns and resource use in the Musi-Banyuasin coastal zone of Sumatra. Marine Research in Indonesia, 19, 109-135.

Hilton-Taylor, C. (Compiler) (2000) 2000 IUCN Red List of Threatened Species. IUCN, Gland, Switzerland and Cambridge, UK.

IUCN (1996) 1996 IUCN Red List of Threatened Animals. IUCN, Gland, Switzerland.

Khan, N. (1995) Protection of north Selangor peat swamp forest, Malaysia. Parks, 5, 24-31.

Kinnaird, M.F. \& O'Brien, T.G. (1998) Ecological effects of wildfire on lowland rainforest in Sumatra. Conservation Biology, 12, 954-956.

Lading, E. \& Stuebing, R. (1997) Nest of a false gharial from Sarawak. Crocodile Specialist Group Newsletter, 16, 12-13.

Lambert, F. (1988) The Status of the White-winged Wood Duck in Sumatera, Indonesia. A Preliminary Assessment. Unpublished Report. PHPA-AWB/Interwader Report no. 4. Asian Wetland Bureau, Bogor.

MacKinnon, K., Hatta, G., Halim, H. \& Mangalik, A. (1996) The Ecology of Kalimantan, Indonesian Borneo. The Ecology of Indonesia Series. Vol. III. Periplus Editions, Singapore. 
Muin, A. \& Ramono, W. (1994) Preliminary Survey of Buaya Sumpit (Tomistoma schlegelii) and Buaya Kodok (Crocodylus siamensis) in East Kalimantan. Unpublished Report. Asian Conservation and Sustainable Use Group and Crocodile Specialist Group, Jakarta.

Müller, S. (1838) Tijdschrift Voor Natuurlijke Gesciedenis En Physiologie, 5, 61-87. Amsterdam, Leyden.

Ramono, W.S. (1994) Tomistoma schlegelii in the Provinces of Sumatra Selatan and Jambi. Unpublished Report. Asian Conservation and Sustainable Use Group, Jakarta.

Ross, J.P. (ed.) (1998a) Crocodiles. Status Survey and Conservation Action Plan, 2nd edn. IUCN/SSC Crocodile Specialist Group, Gland, Switzerland.

Ross, J.P. (1998b) Meetings (notes of the 14th working meeting of the (SG). Crocodile Specialist Group Newsletter, 17, 3-7.

Ross, C.A., Cox, J.H., Kurniati, H. \& Frazier, S. (1998) Preliminary surveys of Palustrine Crocodiles in Kalimantan. In Crocodiles. Proceedings of the 14th Working Meeting of the Crocodile Specialist Group, IUCN-The World Conservation Union, pp. 46-79. IUCN/SSC Crocodile Specialist Group, Gland, Switzerland.

Sebastian, A.C. (1993a) The crocodilians of Malaysia. A review. In Crocodiles. Proceedings of the 2nd Regional (Eastern Asia, Oceania, Australasia) Meeting of the Crocodile Specialist Group, IUCN-the World Conservation Union (Not Numbered). IUCN/ SSC Crocodile Specialist Group, Gland, Switzerland.

Sebastian, A.C. (1993b) The Tomistoma or false gharial Tomistoma schlegelii. The need for its conservation in South East Asia. In Crocodiles. Proceedings of the 2 nd Regional (Eastern Asia, Oceania, Australasia) Meeting of the Crocodile Specialist Group, IUCN-the World Conservation Union (Not Numbered). IUCN/ SSC Crocodile Specialist Group, Gland, Switzerland.

Sebastian, A.C. (1994) The Tomistoma Tomistoma schlegelii in Southeast Asia, a status review and priorities for its conservation. In Crocodiles. Proceedings of the 12th Working Meeting of the Crocodile Specialist Group, IUCN-the World Conservation Union, Vol. 1, 98-112. IUCN/SSC Crocodile Specialist Group, Gland, Switzerland.

Simpson, B.K., Lopez, A., Latif, S. \& Yusoh, A. (1998) Tomistoma (Tomistoma schlegelii) at Tasek Bera, Peninsular Malaysia. In Crocodiles. Proceedings of the 14th Working Meeting of the Crocodile Specialist Group, IUCN-The World Conservation Union, pp. 32-45. IUCN/SSC Crocodile Specialist Group, Gland, Switzerland.

Stuebing, R.B., Lading, E. \& Jong, J. (1998) The status of the false gharial (Tomistoma schlegelii Mueller) in Sarawak.
In Crocodiles. Proceedings of the 14th Working Meeting of the Crocodile Specialist Group, IUCN-The World Conservation Union, pp. 1-9. IUCN/SSC Crocodile Specialist Group, Gland, Switzerland.

Thorbjarnarson, J.B. (Compiler) (1992) Crocodiles. An Action Plan for their Conservation. IUCN, Gland, Switzerland.

Webb, G.J.W., Sack, G.C., Buckworth, R. \& Manolis, S.C. (1983) An examination of Crocodylus porosus nests in two northern Australian freshwater swamps, with an analysis of embryo mortality. Australian Wildlife Research, 10, 571-606.

Whitten, A.J., Damanik, S.J., Anwar, J. \& Hisyam, N. (1984)

The Ecology of Sumatra. Gadjah Mada University Press, Yogyakarta.

Witkamp, H. (1925) Een en ander over Krokodillen in Koetai. De Tropische Natuur, Jaargung XIV. Aflevering II, Buitenzorg.

\section{Biographical sketches}

Mark Bezuijen, a zoologist, has worked on conservation projects in South-east Asia and northern Australia for the past 12 years. He is a member of the IUCN-SSC Crocodile Specialist Group. His specific interests include the conservation biology of crocodilians and sustainable use of wildlife. He is currently a zoological consultant in southeastern Australia.

Prof. Grahame Webb, a zoologist, has worked extensively on crocodilian ecology, population dynamics, conservation, and management, particularly of saltwater crocodiles in the Northern Territory, Australia. He is a Regional Vice-Chairman of the IUCN-SSC Crocodile Specialist Group, and Chairman of the IUCN-SSC Australia-New Zealand Sustainable Use Specialist Group. He is the director of Wildlife Management International, an Australian-based consulting company, and an Adjunct Professor at the Northern Territory University.

Pandu Hartoyo and Samedi have been involved with Indonesian wildlife conservation for more than 15 years, including national policy development, captive breeding of endangered species and wildlife trade issues. Mr Hartoyo is currently a conservation consultant and Dr Samedi works in the CITES Management Authority of Indonesia. 